\title{
THE MYSTICAL ORNITHOLOGIST AND THE IOWA TUFTHUNTER: \\ Two Unpublished Whitman Letters and Some Identifications
}

ED Folsom

There ARE TWo unpublished letters from Walt Whitman in the Special Collections of The University of Iowa. ${ }^{1}$ Neither offers earthshattering revelations, to be sure, but each is involved in an interesting story, and both illuminate some heretofore murky identifications in Whitman's Daybooks.

The first letter is to Thomas G. Gentry, and should follow letter No. 1262 in Edwin Haviland Miller's edition of The Correspondence (New York: New York University Press, 1961-1977); Whitman's letter is a response to this request from Gentry:

Germantown, Pa., / February 8, 1884

Mr. Walt Whitman,

Dear Sir:-

Since the completion of my late work on "Nests \& Eggs of Birds of the U.S.," I have been engaged in preparing a book on bird-poetry. Would like to include your poem on "The Man-of-War Bird," if you have no objection. Anything else that you would like to appear, will be given a place, if you will call my attention thereto. Trusting to hear from you soon,

I remain

Yrs., \& c., Thos. G. Gentry.

Whitman promptly responded by writing on the back of Gentry's letter:

Dear Sir

Camden New Jersey / Feb. 11 '84

I am entirely willing you should print the piece, as you request -

Walt Whitman

Gentry (1843-1905) was an ornithologist from "Germantown, Philadelphia" (as he preferred to locate himself in the prefaces to all of his books). His Nests and Eggs of Birds of the United States had been published in 1882 and was his sixth book; earlier works included such forgotten volumes as $O n$ Habits of Some American Species of Birds (1874) and The House Sparrow at Home and Abroad (1878). He was a member of several respected professional organizations including the Academy of Natural Sciences of Philadelphia, the Nuttall Ornithological Club, and the Canadian Entomological Society, and was a frequent contributor to solid scientific journals like the Proceedings of the Academy of Natural Sciences and The Auk during the 1870s and the 
early 1880s. At first glance it would appear that he was a respected if unremarkable scientist, who followed many like him into obscurity.

But there was more to Gentry's story: by the time he wrote to Whitman his professional reputation had already begun a remarkable decline, as seen in a long review of his book, Nests and Eggs of Birds in the United States, in the authoritative Bulletin of the Nuttall Ornithological Club (The Auk) in 1882. It was the kind of notice one does not easily recover from. The reviewer was clever in the way he moved in for the kill:

... we are given an amount of detail and exact data, concerning some of the most inaccessible points connected with the breeding habits of birds, that excite, first, admiration (for the author's extraordinary acuteness of observation); next, astonishment (at the possibility of attaining a knowledge of certain peculiarities mentioned); and finally, incredulity (regarding the reliability of the author's statements).

And this was only the beginning; Gentry's work, said the reviewer, has "the stigma of untrustworthiness," is "unreliable and worthless . . . trash," at best "well-adapted for the amusement of children," and its few admirable parts are plagiarized. Twenty years later the same journal printed a review of an even earlier Gentry work, Life-Histories of the Birds of Eastern Pennsylvania (1876). This two-volume study, the reviewer says, was rightfully ignored when it first appeared, but now-to the horror of the reviewer and other scientists - it was being accepted as a factual record by some unsuspecting scientists in England. There seems to have been an odd conspiracy of gentle silence about Gentry's works: "As if by common consent they have been very consistently ignored by American ornithologists," says the reviewer, who admits that he himself "has up to the present acquiesced in the silent treatment of Gentry's volumes." But now, seven years after Gentry's death, the reviewer feels a duty to let the ornithological world know that this "glib author" offers a "dangerous mixture of fact and unfact," and that the major revelations of Gentry's study are "almost entirely products of the author's imagination." The reviewer then carefully dissects Gentry's various claims and reveals them to be patently false. ${ }^{2}$

So by the time Gentry wrote to Whitman, his ornithological career was virtually over; he wrote no more scientific books about birds, and his name faded from the membership rolls of the various scientific societies he had belonged to (his death is not recorded in any of their journals). Gentry's attention turned instead to projects like a biography of his friend, the famous paleontologist E. D. Cope (to whom Gentry dedicated some of his questionable works, with lavish thanks to Cope for his careful review of the manuscripts!), and a book on Family Names from the Irish, Anglo-Saxon, AngloNorman and Scotch Considered in Relation to Their Etymology (1892). The anthology of bird poetry that he wrote to Whitman about apparently never materialized, perhaps because of his own growing disrepute, or perhaps 


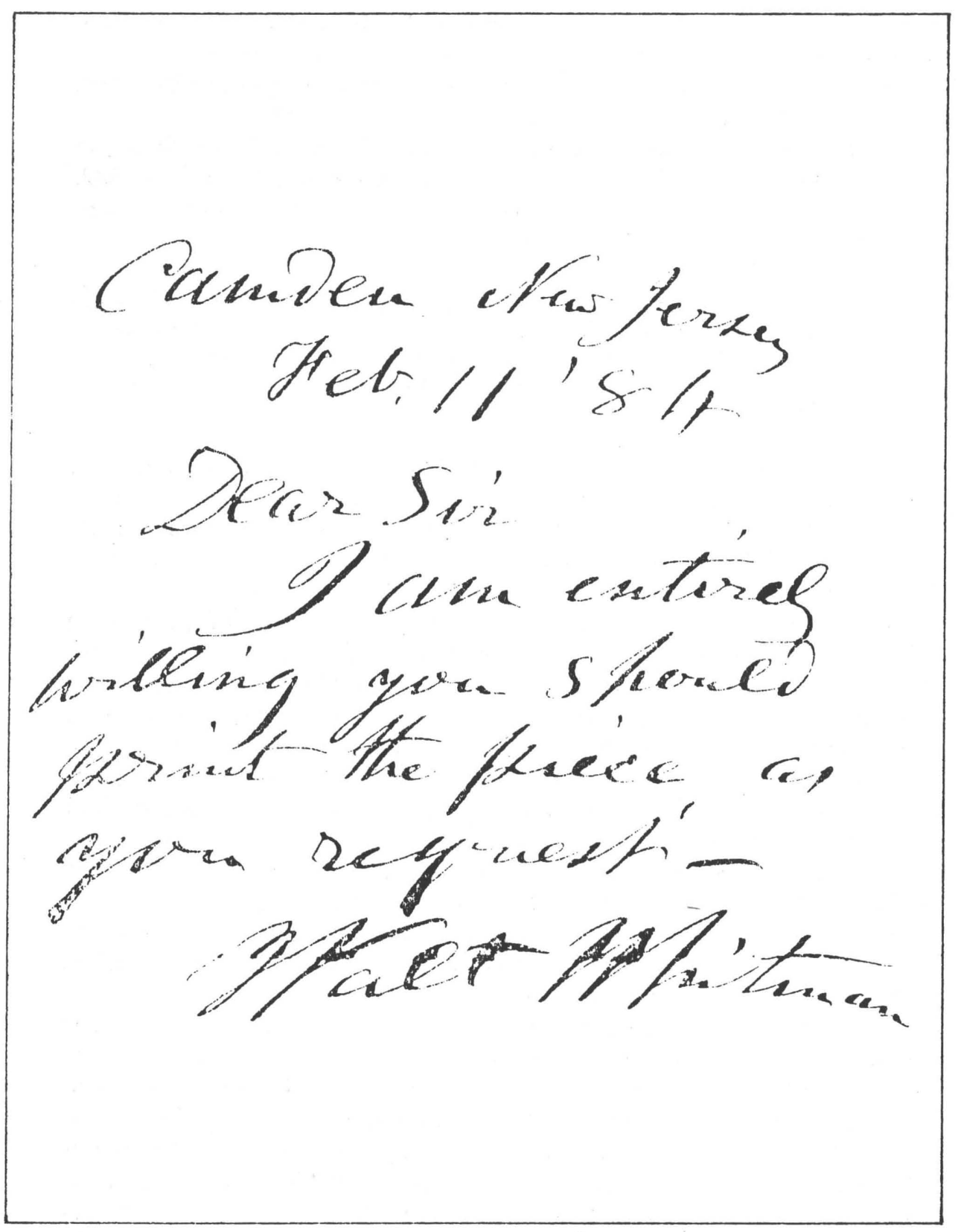

Letter from Whitman to Thomas Gentry.

20 
because the publishing market experienced a surprising surfeit of such books around this time (Mrs. A. N. Bullers's Silver Voices: Poems of Bird Life appeared in 1887, followed by D. R. Goodale's Birthday-Book of Birds: Verses and J. Pollard's Favorite Birds, and What the Poets Sing of Them in 1888, and Rosetta Munroe's With the Birds: Selected Poems from English and American Authors in 1891; A. O. Churchill's Birds in Literature would not appear until 1906). ${ }^{3}$

The abandonment of this project, though, did not affect Gentry's growing fascination with Whitman. In Whitman's Daybook for October 1885, Gentry's name and address suddenly appear, nearly two years after his letter to Whitman. And apparently he and his son paid Whitman a visit on December $30,1885.4$ There is nothing to suggest what might have prompted the visit, but certainly Gentry's own life had been moving away from scientific investigation increasingly toward a philosophical and transcendental exploration that might well have drawn him to Whitman and his work. Indeed, Gentry's later years were spent writing and revising his major workan odd mixture of science, fantasy, philosophy, and religion called Intelligence in Plants and Animals (published by Doubleday, Page in 1900 after Gentry had published an earlier version, Life and Immortality, or Soul in Plants and Animals, in 1897). This work was preceded by Gentry's own book of poems, Pigeon River, published in 1892, a collection of pedestrian verse filled with addresses to and images of birds - "To the Wood Thrush," "To the Song Sparrow," "The Towhee Buntings"-but also suffused with an extreme sadness brought on certainly by the death of his wife and perhaps also by his own diminishing professional stature:

\footnotetext{
'Tis vain to kneel beside the graves Of buried hopes and pleasures,

And sigh for the companionship

Of those decaying treasures.

'Tis vain to brood o'er hours misspent

In idleness and sorrow,

And seek to expiate their loss

By begging from the morrow.
}

This tone of romantic melancholy permeates the book, which ends with "Dark Days," a poem that seems to define Gentry's state of mind during the 1890s ("Dark are my days and cold and drear"); his comforting birds have vanished from his life:

No more the robins joy and sing

By breezy lanes, secluded hollows,

Nor trip the air on purple wing

The sun-adoring, lissome swallows. 
And he concludes:

Alas! it is my life seems dead,

Crush'd 'neath a mountain-weight of sorrows,

Else would my soul with Nature wed,

And live with her the unborn morrows. ${ }^{5}$

So it is not surprising that the remainder of Gentry's life was dedicated to discovering just how to wed his soul to Nature's soul, to break out of his melancholy. This struggle is recorded in Intelligence in Plants and Animals, an exhaustive investigation of how such animals as bees, ants, worms and buzzards, as well as all kinds of plants, display intelligence and thus have souls, how the "possession of soul and spirit can be predicated no less of plants than of man and the lower animals." "There is soul, in some sort of development, in everything . . . "Only by embracing such a belief, says Gentry, can "all life [be] related to the Divine life, can there be any hope of escape from materialism, that curse of the age." He sets out to prove that even the "lower animals" will have "a future life, where they will receive a just compensation for the sufferings which so many of them undergo in this world." He posits a firm belief in Spencerian evolution: "Man is in reality but on the threshold of civilization." He uses the Bible and poets and scientific observation to support his ideas. The life-soul continually moves through and among the vast variety of forms: "The spirit of man must have entered into the spirit of the plant," he affirms, and so it is easy to see why Gentry would have been attracted to Whitman's poetry, where he would have read, "I reach to the leafy lips, I reach to the polish'd breasts of melons." Gentry found intelligence in such things as the Finger Slime, and thus often echoes Whitman's faith: "To be in any form, what is that? / (Round and round we go, all of us, and ever come back thither,) / If nothing lay more develop'd the quahaug in its callous shell were enough." And Gentry certainly would have endorsed Whitman's ability to "turn and live with animals, they are so placid and self contain'd / . . They bring me tokens of myself ..." "Not alone are we of the upper walks of being made the possessors of the inner life," concludes Gentry, "but all nature shares it in common with us, and love is its expression and the method of its action."'

It is clear then why Gentry had a fascination with Whitman's "To the Man-of-War-Bird," a poem about the possibility of instilling soul in the bird, about the desire of the human soul to attain the bird's vast vista: “... had'st thou my soul, / What joys! what joys were thine!" Like many of Gentry's own bird poems, Whitman's poem posited the possibility that man could talk to birds, address them. Had Gentry completed his anthology, he might well have included other Whitman poems that he must have been attracted to, especially the "carol of death" sung by the thrush in "When Lilacs 
Last in the Dooryard Bloom'd" where "the voice of my spirit tallied the song of the bird." What the ornithological community upbraided Gentry for-infusing his scientific catalogues with flights of fancy-might well have been just what would have made him an interesting visitor for Whitman in the last years.

The other Whitman letter in the Iowa collection also is to an ornithologist; his name was Charles Aldrich (1828-1908). The Auk (in the same volume in which Gentry is denigrated) referred to Aldrich as one of the fifty "more prominent ornithologists of the United States and Canada." As a member of the Iowa House of Representatives, Aldrich successfully sponsored legislation to protect "from wanton destruction the harmless and useful birds." ${ }^{\prime 7}$ His letter to Whitman, however, has nothing to do with birds, and it should follow No. 1279 in The Correspondence:

Dear Sir

328 Mickle Street / Camden New Jersey / June 12 ' 84

I send you, same mail with this, a copy of the $\$ 3$ autograph edition of Leaves of Grassyours of some weeks since sending $\$ 2$ was received-leaving $\$ 1$ due-which please enclose in letter \& send me here.

Walt Whitman

This letter is like many others Whitman wrote (it is in fact very much like No. 1279, which precedes it), and adds one more bit of evidence to the record of Whitman's often-meticulous bookkeeping that E. H. Miller analyzes so thoroughly in the introduction to Volume 6 of The Correspondence (it also serves to correct one entry on Miller's list of "book orders" for Leaves of Grass in 1884 [p. xxx]: "A. Aldrich" should read "C. Aldrich"). An entry corresponding to Whitman's letter to Aldrich appears in the Daybooks (2:335), with a red "paid" carefully marked in after the "\$1 due" that appears by $\mathrm{Al}$ drich's name; this was the first of several sums of money Aldrich would send to Whitman. Nearly 20 years later, Aldrich still wrote about his "good fortune ... to purchase a copy [of Leaves] from the author himself." It was a volume that meant a great deal to him; although he appears only once very briefly in Gay Wilson Allen's The Solitary Singer-where he is misleadingly referred to as "a librarian in Iowa, who strongly disapproved of Whitman's poems"9-Aldrich actually had a long and rewarding relationship with Whitman.

To call Aldrich simply a "librarian in Iowa" is to reduce significantly the variety, scope and influence of his life, and to miss what made him most interesting to Whitman. He was a newspaperman from upstate New York who shared several important experiences with Whitman; both were apprentices on newspapers in their teenage years, and both established their 
328 thithe streed Famben chew perpey foue I 12 'six

Deres sis

? dene you, same mait with thin, a cortay of

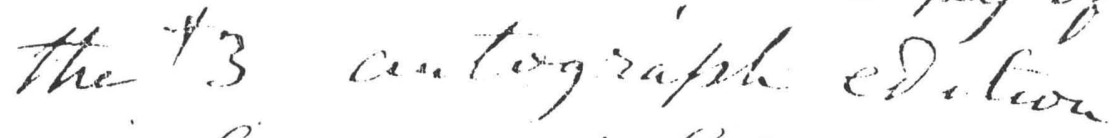
of Lewer of lisate

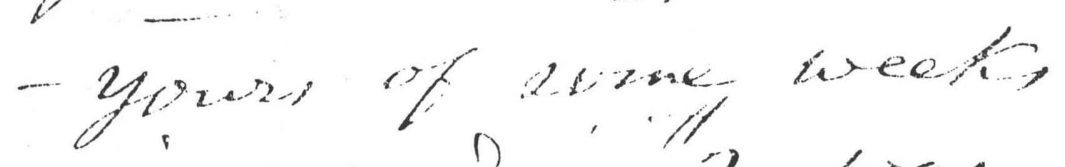

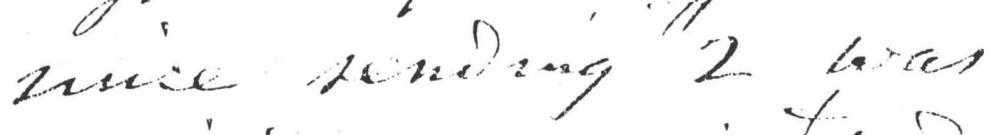

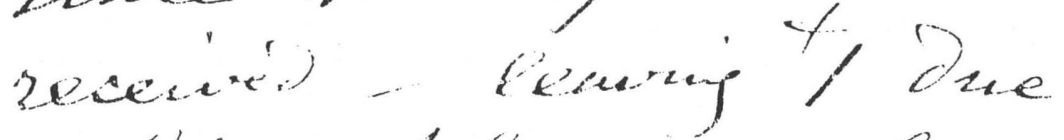
which thanes enclize in lelter \& knd he here.

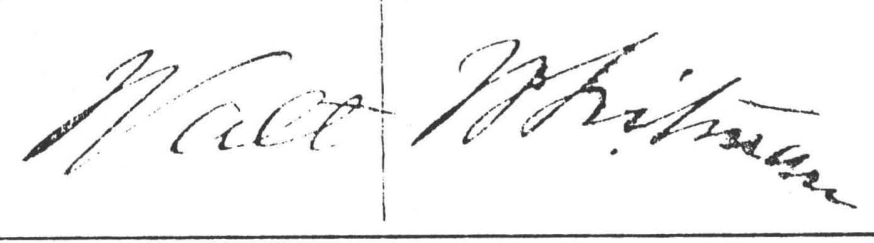

Letter from Whitman to Charles Aldrich.

24 
own papers when they were around 20 years old. By 1848, both were avid Free Soil party members and attended the first Free Soil Convention; they both edited Free Soil newspapers, Whitman the Brooklyn Freeman and Aldrich, somewhat later, the Hamilton Freeman in Iowa, where he had gone to seek out the adventure of the frontier and to start a newspaper in a young, unformed community; his impassioned editorials against the extension of slavery sound very much like Whitman's. Later, in addition to his previously mentioned ornithological work, Aldrich published several other papers, was a Captain in the Iowa Infantry in the Civil War, became Chief Clerk of the Iowa House of Representatives, served as a state Representative, then founded the Iowa Historical Department and was its director and curatorand founding editor of its journal, Annals of Iowa-for the final 20 years of his life. He was also a voracious lifelong autograph collector, and it was this hobby that first led him to write to Whitman and to purchase from him an autographed edition of Leaves of Grass.

But that purchase was only the beginning. "That is a very hungry manAldrich," Whitman told Horace Traubel in 1889; "He has been here-has had autograph, what-not. But is never satisfied-is always crying for more and more." Indeed for the next six years Aldrich did continue to write to Whitman requesting autographed material, and he visited the poet in Camden at least four times - twice in 1885, once in 1886, and again in 1888. Each time, he came away with more signed mementoes which he took back to Des Moines and added to his vast collection, a collection he eventually gave to the state of Iowa in $\mathbf{1 8 8 4}$ as the foundation for a state archive. He had special cases hand-made to display his materials, which are still on view in Des Moines.

Aldrich managed to get from Whitman five signed portraits, a portrait of Whitman's mother, and two manuscripts. One of these MSS, which Whitman sent him in 1885 (this is the unidentified MS mentioned in the Daybooks, p. 351), is a valuable fragment: a holograph page of Whitman's essay "Abraham Lincoln" which first appeared in Allen Thorndike Rice's Reminiscences of Abraham Lincoln (1886). This holograph, which has heretofore gone unnoticed (it is not mentioned in Floyd Stovall's edition of Prose Works 1892), shows a great deal of revision (around 25 deletions, additions or substitutions on one short page) and even suggests that Whitman conceived of the essay as another of his Lincoln lectures (he carefully writes in a pronunciation note to himself for "Alcinous").

We learn something, too, of Whitman's economy by examining this page, since it is made up of two scraps of paper pasted together. The reverse side reveals that one scrap was actually Whitman's notification for his 1878 annual free pass on the West Jersey Railroad. (This fact must have unsettled Aldrich when he received the manuscript, since he was just then immersed in a controversy over the practice of railroads giving free passes to public 
officials and famous personages. Aldrich fought this practice vigorously, introduced legislation in the Iowa General Assembly to prohibit it, and found his remarks about free passes widely reprinted; in fact he achieved his greatest national notoriety during this controversy-see, for example, his essay in the January, 1884, North American Review. $)^{10}$

But with mixed feelings or not, Aldrich carefully preserved this manuscript, for he always loved the handwriting of the famous. He literally traveled the world to procure autographs and photos, and it was during one of these trips that he became good friends with Whitman's English editor and supporter, William Michael Rossetti. Aldrich and Rossetti had carried on a lively correspondence about autograph-collecting, an avocation Rossetti also indulged in. In fact, Rossetti and Aldrich exchanged many autographs, and on several occasions Rossetti furnished Aldrich with large selections of letters from his personal collection of correspondence. He sent the letters to Aldrich complete with a long list of annotations about the letter-writers. Aldrich's growing autograph collection with its prized Rossetti additions gained enough notoriety to be described at length in national journals like The Critic. (It was the 1889 notice in The Critic that prompted Whitman's outburst about Aldrich being a "very hungry man.")"11

And in 1885, it was Aldrich who brought to Rossetti's attention the deplorable conditions in which Whitman was living in Camden. Following a visit to Walt on a frigid snowy day in February, Aldrich wrote to Rossetti about Whitman's illness, poverty and lack of good care; Aldrich reported that the poet "seemed to me to be in a condition of wretched poverty." After receiving a response from Rossetti that seemed somehow to miss the point, Aldrich wrote a second, more alarming letter in May; this time Rossetti was upset by the news and sent the letter on to his friend (and Whitman's ardent admirer) Anne Gilchrist, who was concerned but puzzled, since she had only days before received a comforting and contented note from Whitman about his "nook in Mickle Street" where he doubted "if I could be better provided." But Aldrich's distressing letter was enough to make Mrs. Gilchrist's longtime ardor for Whitman flare once more. In the final months before her death she convinced her son Herbert and her friend Rossetti to advertise, organize, and administer a "free-will offering" for Whitman's benefit. Aldrich contributed twice to the fund, the only American to donate, and after Whitman's death he wrote an article for The Critic chastizing his countrymen for their relative neglect of Whitman compared to the efforts of his British friends. Aldrich, then, was responsible for getting Whitman's two most faithful English admirers to devote their energy and effort one more time in Walt's behalf. ${ }^{12}$

In 1886 Aldrich visited England and spent time with Rossetti and his family. He checked in on Whitman in Camden both on his trip to England and on his return, carrying messages to and from Rossetti. By the time he 
visited Whitman on his return trip, he was able to bring good news about the success of the fund drive, and indeed a large installment arrived in Camden just after Aldrich did. The money from this fund was a major source of Whitman's income during this time, and according to Aldrich "enabled Whitman to live comfortably - for him."13

In the summer of 1888 Aldrich again visited England and spent a good deal of time with Rossetti. And once again, on his return to America (in October), Aldrich visited Whitman. This time he told the poet about a dinner party he had attended at Rossetti's home during which a Frenchman mentioned an article in French about Whitman. Whitman, of course, was curious about the essay and its author, and a week later Aldrich sent Whitman the information - the name and address of Gabriel Sarrazin. Thus Aldrich helped initiate one of the warmest and most satisfying relationships of Whitman's last years.

It is clear, then, why Whitman - despite his reservations about Aldrich's hunger for autographs - would recall that "Charles Aldrich is my good friend: he has ideas, faiths, which lead him affectionately my way." It is not so clear, however, why Gay Wilson Allen characterizes him as a person "who strongly disapproved of Whitman's poetry." All the evidence is to the contrary. Indeed Aldrich in 1903 wrote an essay on "Walt Whitman and James Harlan" in which he says of Whitman that he "was too great to need defense from anybody." Aldrich was one of the few people-if not the only personwho was in a position to judge the Harlan-Whitman affair evenly, since he was a personal friend of both the politician and the poet. In his article he defends Iowa's former Senator by asking readers to try to understand Harlan's conventional morals and to try to forgive his understandable tendency to share "the popular estimate" of Whitman's work as "indecent." Aldrich makes clear that he himself does not share that estimate, but instead is proud to have known this great poet. ${ }^{14}$

Aldrich's last correspondence with Whitman took place in 1889-1890, and involved, of course, a final request for another autograph, this time a manuscript copy of "O Captain! My Captain!" so that he could put it on display in the Capitol at Des Moines (where it today remains in the Historical Building). After delaying a half year, Whitman finally obliged, and Aldrich promptly sent him $\$ 5$ in return, the last money he gave to Whitman.

Rossetti, recalling Aldrich, said, "I never met a man to whom the duties of citizenship seem to come more natural ... At an advanced age he continues to work hard, and always with a public end in view." And Whitman, describing Aldrich to Traubel, said, "He is . . . a very likeable man-I suppose what they would call in England a tufthunter ... Though that is not peeping out, so far as I could see-not making itself obtrusive . . He is from Iowa. . . . I noticed that he had a little touch of local pride ..." This likeable tufthunter's local pride must have been stirred each time he looked 
at the "O Captain!" manuscript, for at the bottom of the page Whitman had written in a bold hand: 15

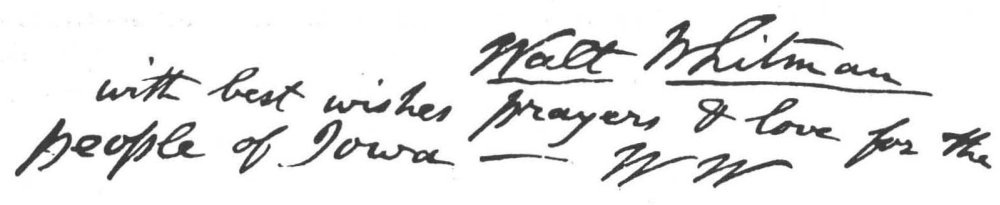

The University of Iowa

\section{NOTES}

1 These letters are reprinted by permission of the Special Collections Department, University of Iowa Libraries. In addition to these two letters, the Iowa library also owns the original of letter No. 819, a Whitman postcard to John Burroughs, which Edwin Haviland Miller printed from a transcription by Thomas Ollive Mabbott.

2 The first review appeared in the Bulletin of the Nuttall Ornithological Club (later The Auk), 7 (1882), 246-249. The second review was in The Auk, 29 (1912), 119-121.

3 Gentry had a regrettable tendency to announce books that never appeared; in Vol. 2 of his History of the Birds of Eastern Pennsylvania he announced that a third volume was imminent. It never appeared.

4 William White, editor, Daybooks and Notebooks (New York: New York University Press, 1978), 2:371. There is no identification of Gentry in the notes.

5 Pigeon River and Other Poems (Philadelphia: Burk \& McFetridge, 1896), pp. 9, 47.

6 Intelligence in Plants and Animals (New York: Doubleday, Page, 1900), pp. 3, 478, 489, $423,488,489$.

7 The Auk, 8 (1883), 222; John M. Brainard, Charles Aldrich, Annals of Iowa, 8 (January 1909), 563-571. Other information on Aldrich can be found in this same issue of Annals, a memorial issue honoring Aldrich. See also Ora Williams, "The Iowa Historical Department," Annals of Iowa, 23 (1941-42), 267-286; Bessie L. Lyon, "Journalism Comes to Hamilton County," Annals of Iowa, 32 (October 1954), 446-459. Aldrich appears several times in The Correspondence (3:452; 4:230, 440; 5:57) and in Daybooks and Notebooks (2:335, 351, 352, 377, 477, 560).

8 Charles Aldrich, "Walt Whitman and James Harlan," Annals of Iowa, 6 (October 1903), 225.

9 The Solitary Singer (New York: New York University Press, 1967), p. 524.

10 Traubel, With Walt Whitman in Camden, edited by Gertrude Traubel (Carbondale: Southern Illinois University Press, 1964), 5:444; Aldrich, "The Building of an Autograph Collection," Annals of Iowa, 9 (July 1909), 81-94.

11 Rossetti talks about autograph collecting in Some Reminiscences of William Michael Rossetti (New York: Scribner's, 1906), 2:510-511. Some of his lengthy correspondence with Aldrich has been published in Clarence Gohdes and Paull Franklin Baum, editors, Letters of William Michael Rossetti Concerning Whitman, Blake, and Shelley (Durham: Duke University Press, 1934); some 20 letters from Rossetti to Aldrich are in the unpublished Aldrich 
papers in the Iowa State Historical Department, Division of Historical Museum and Archives, in Des Moines, and many of them discuss autograph-collecting. Also in the Aldrich papers is a letter from Herbert Gilchrist to Rossetti, dated September 14, 1885, dealing with donations to the free-will offering. Rossetti also sent Aldrich two envelopes addressed by Whitman to Rossetti; these too are in the Aldrich papers. When Aldrich gave part of his Rossetti collection to the University of Iowa, he apparently substituted for one of these envelopes the letter that Whitman had sent to him about the autographed edition of Leaves of Grass.

12 The Critic, 20 (April 23, 1892), 245-246; The Correspondence, 3:392-393.

13 See E. H. Miller's "Introduction: Walt Whitman's Income, 1876-1892" in Vol. 6 of The Correspondence, especially pp. xvi, xxx-xxxi. Aldrich's comment is in The Critic, 20 (1892), 246.

14 Horace Traubel, With Walt Whitman in Camden (1908, rpt. New York: Rowman and Littlefield, 1961), 2:292; Aldrich, "Whitman and Harlan," Annals, 6 (1903), 225-227.

15 Rossetti, Reminiscences, 2:509; Traubel, With Walt Whitman in Camden, 3:2. The "O Captain!" manuscript is in a display case in the Iowa Historical Museum in Des Moines. 